\title{
Currency Crisis in Bangladesh Economy: Some Insights
}

\author{
A. F. M. Ataur Rahman ${ }^{1, *}$, Reshman Hasan ${ }^{2}$ \\ ${ }^{1}$ Associate Professor, Department of Economics, North South University \\ ${ }^{2}$ Reshman Hasan, Department of Economics, North South University \\ *Corresponding author: ataur19@yahoo.com
}

Received December 14, 2013; Revised January 04, 2014; Accepted January 20, 2014

\begin{abstract}
Many countries around the world have faced currency crisis where they experienced substantial devaluation of local currency vis-à-vis some strong international currency within a short span of time resulting disruption in nominal as well as real activities. Although Bangladesh is not one of them yet in an integrated world possibility of experiencing such crisis is not remote. Using the concept of Exchange Market Pressure (EMP) in this paper we have tried to measure pressure on exchange rate in Bangladesh and then tried to find an early warning indicator of building EMP for Bangladesh. We found that in some occasions exchange rate situations got little erratic but never to the extent of crisis. We also found that before building up exchange rate pressure current account is most probably to show an early warning for Bangladesh. And ratio of M2 and reserve actually moves along with EMP index, so it may not be too informative for identifying currency crisis beforehand.
\end{abstract}

Keywords: bangladesh economy, Exchange Market Pressure, crisis

Cite This Article: A. F. M. Ataur Rahman, and Reshman Hasan, "Currency Crisis in Bangladesh Economy: Some Insights.” Journal of Finance and Economics, vol. 2, no. 1 (2014): 7-16. doi: 10.12691/jfe-2-1-2.

\section{Introduction}

In the era of globalization, currency crisis seems to be not an exceptional phenomenon. It, when happens, not only disturbs the financial sector of an economy but also affects the smooth operation of its real sector. Although researchers do not quite agree regarding the channels through which disturbances in nominal sector is passed on to real sector, yet they mostly agree that the level of integration between these two parts of the economy is quite high resulting the currency crisis to affect real sector. When the effects of currency crisis flow into real sector then it creates political problems as well. People lose their jobs; have to cut their consumption, domestic savings declines, future development potential gets hampered and so on.

Apart from this political aspect the issue is important technically as well. The interactions between real sector and different parameters of nominal sector are so complicated and include so many dimensions that we still are not in a position to predict with certainty the outcomes in real sector when nominal variables are disturbed. More work need to be done on this issue. However this exercise is not an attempt to produce theory in this literature. Rather we would like to get some insight in the possibility of occurrence of currency crisis in Bangladesh following existing theory. Currency crisis is a sufficiently big issue for an economy and it is expected that the economy will show some indications before its appearance. These indications can be the causes or leading indicators of currency crisis. It is quite difficult to make such distinctions given the interrelated nature of macro variables. Some leading indicators are what we would like to identify. Analyzing historical development of relevant macro-economic variables of Bangladesh we would like to identify periods when currency position faced pressure and if possible identify a set of variables that move before building up any pressure on currency situation.

There is an enormous amount of literature on this issue. Early theoretical models suggest the possibility of predictability of crises even with fully rational speculators (Known as First Generation Models). A central notion of these models relied solely in the behavior of the speculators as the crisis and its timing would be fully predictable if they wait until reserves are below some critical level before they attack. In contrast to the concentration on inconsistent balance between currency peg and other economic policies as per the First Generation Models, changes in equilibrium (for example, from the pegged regime to the devalued or floating regime or another) instead of deterioration in fundamentals were prioritized in Second Generation of Models.

As an opponent of self-fulfilling crisis in Second Generation Models, Third Generation Models incorporated the notion of contagion effects. All of these theoretical models, however, rest heavily on theoretical aspects rather than practical applications in real world.

These however indicate that the literature is not quite certain regarding the formation or development of a currency crisis. Therefore, Early Warning System (EWS) models; such as, Econometric Approach and Nonparametric approach emerged to predict crisis. There is a quite a bit of work following ad hoc or non parametric model based arguments.

Rest of the paper is organized as follows. The next section discusses relevant literature followed by a 
discussion on some relevant aspects of Bangladeshi economy. Methodology is presented in section 4. Section 5 discussed empirical findings and the discussion concludes with section 6 .

\section{Literature Review}

We can identify three different generations of models to explain currency crisis. The first generation models are theoretical ones and emerged as a consequence of the Latin American debt crisis at the beginning of 1980s. Developed on the arguments presented in Salant and Henderson [1] on speculative attacks on governmentcontrolled price of gold, Krugman [2] introduced his model which assumed inevitable speculative attack in a fixed exchange rate regime when agents change composition of their portfolios from domestic to foreign currency, for instance, because of suspecting devaluation due to rising fiscal deficit. Crisis, then, may be triggered as a natural consequence as in that situation central reserve will be no longer enough to defend its currency (Chiodo and Owyang [3]).

Flood and Garber [4] later developed a linear version of the Krugman [2] model for small economy. Though their model forecasted lower bounds for post-collapse exchange rates in a stochastic framework in access to predicting the timing and the probability of endogenous attack, likewise other deterministic models it considered attacks are predictable.

First Generation Models dealt with a wide array of occasions. These models demonstrated that crisis not necessarily occurs due to irrationality of market participants, instead it arises due to their very rational expectations (Jeanne [5]). For instance, if reserve does not flee, speculators could forecast the period of devaluation and thus could be able to make sure profits. The core of this speculative-attack approach claims that reserve flight occurs during a currency crisis due to rational arbitrage.

In general, these models coin their arguments on weak economic and financial fundamentals of a certain country which can make that country very suitable for speculative attack by international short term financial investors. Thus these models try to identify indicators of currency crisis. However, they are reluctant to identify underlying causes behind the crisis (Jeanne [5]). Moreover, they could not explain the rationale behind the spillover effect of crisis to other countries (Chiodo and Owyang [3]).

Exchange Rate Mechanism (ERM) crisis of European Monetary System (EMS) in 1992-93 in Western Europe and crisis in Mexico in 1994-95 nullified the strength of First Generation Models as despite having sound fundamentals in terms of adequate international reserves, manageable domestic credit growth and non-monetized fiscal deficits, and good economic policies, some countries enormously failed to build protective shield against speculative attacks. Therefore, a broader and more holistic definition of determinants of currency credibility was required. As a result, a contentious argument was raised that the speculation did not entirely rely on economic fundamentals, rather it was also self-fulfilling.

Features of self-fulfilling prophecies were entailed for developing Second Generation Models as per Obstfeld [6,7], Obstfeld and Rogoff [8], Bensaid and Jeanne [9], and Velasco [10]. These models incorporated the role of "expectations" of economic agents in predicting currency crisis and allowed for "multiple equilibria" while assuming monetary and fiscal policies to be exogenously set; thus these models shifted attention away from the foreign exchange reserves at central bank, the core of speculative attack in the models of Krugman [2] and Flood and Garber [4], to the decision exercising ability of an optimizing policymaker so as to devalue domestic currency. The momentum of currency movement is exposed to the degree at which private agents coordinate and hence multiple equilibria occur.

Second Generation of Models, termed as "the escape clause" models, views fixed exchange rate arrangements as conditional commitment devices of a country which is often dependent on the will of policymakers. A currency crisis, in this scenario, may arise if private agents perceive government's propensity to exercise the escape clause given the existing conditions, and their beliefs about the policymakers' objective.

In contrast to the economic fundamental driven first generation models, escape-clause model has more rational approach over the speculative-attack models by introducing any variable that catalyzes the policymakers' decision to defend the fixed peg. Furthermore, it includes soft fundamentals such as, foreign exchange market participants' perception of fixed exchange rate arrangement or policymakers' reputational capital. Furthermore, self-fulfilling speculation and multiple equilibria are significant contribution of these models as they aid in considering circular causality between fundamentals and market speculation (Jeanne, [5]).

Conflict on numerous competing objectives of policymakers, was indeed a feature of the escape-clause model, but it can be thought aside of multiple equilibria. Multiple equilibria are not a spontaneous suggestive development of these models; rather it is favored due to multifaceted nature of economic factors. Economic fundamentals, however, may accompany the crisis as per Obstfeld [7] and Jeanne [11], but to the extent that their deterioration relates vulnerability of fixed exchange rate system to self-fulfilling speculation. In retrospect, if speculation is said to be self-fulfilling, speculators would be the scapegoat allowing policymakers to exercise the escape clause. The escape-clause model, nonetheless, approaches that self-fulfilling and fundamentalist views are not mutually exclusive. At first fundamentals must be in fragile state to initiate self-fulfilling speculation and then both exacerbate currency vulnerability.

The Third Generation Models evolved with the Asian and the Tequila crisis during the mid 1990 in order to step out from traditional realm of theory by shifting interest from sound economic fundamentals to incompetent financial structure. In this regard, Radelet and Sachs [12] asserted the notion of Second Generation Models by suggesting that self-fulfilling panics at first hit the financial intermediaries, then confirm the panic by forcing liquidation of long run assets. In addition, Masson [13] based on the notion of the "contagion" ascribed that mere occurrence of a crisis increases the likelihood of a similar crisis elsewhere. Furthermore, he projected three related scenarios to represent the contagion: monsoonal effects, spillover effects and pure contagion effects. 
Chang and Velasco [14] ascribed herding effect as "information cascade" and proposed that a correlation between currency crisis and banking crisis may prevail if local bank have debts denominated in foreign currency. Conversely, Burnside, Eichenbaum, and Rebelo [15,16] argued that government may provoke vulnerability in both currency and banking system if it guarantees banking system and thus gives incentive to take foreign debt. Besides, according to Chiodo and Owyang [3] rising interest rate can introduce moral hazard problem when firms' access to loan is constrained by only a portion of their wealth. Increase in domestic interest rate in turn increases the perceived default risk and forces bank to restrict lending.

According to Third Generation Models it is evident that external liquidity is a crucial factor in financial and currency crises (Mckinnon and Pill, [17]; Chang and Velasco, [18]). Moreover, these models mainly examine the role of monetary policy in a currency crisis. These models argue that fragility in the banking and financial sector reduces credit availability and increases the likelihood of a crisis. On a whole, a notorious combination of high debt, low foreign reserves, falling government revenue, rising expectations of devaluation, and domestic borrowing constraints could lead to currency crisis.

On a whole, three generations of models imply four influential factors are able to manifest the onset and magnitude of currency crisis: domestic and private debt, expectations, financial market's vulnerability to pegged exchange rate and magnitude and success of speculative attack. Third Generation Models was developed later on as it included the financial sector indicators derived from aggregate balance sheets of banks; Krznar [19] however singled out the inconsistencies of using different determinants as major drawbacks in offering consensus on causes of financial crises. After attaining coherence in identifying determinants of financial crisis, mainly three significant approaches are proven to be beneficial in developing Early Warning Models:

i. The linear-dependent variable approach;

ii. The Econometric approach (discrete-dependent variable approach); and

iii. The signals approach (leading indicator approach).

Sachs, Tornell and Velasco's [20] attempting to analyze the Mexican Crisis in 1994-95 along with its aftermath, commenced the Linear-Dependent variable Approach. This approach introduced a dependent variable equivalent to a crisis index, which was essentially a weighted average of the devaluation of exchange rate against US Dollar and the percentage change in foreign exchange reserves.

The Econometric Approach incorporates limited dependent probability models (such as a probit or Logit model) to estimate a probability relationship with a discrete dependent variable (one or zero, or a crisis occurs or does not occur). This approach can suggest predictive power of different explanatory variables, and thus is able to demonstrate the probability of future crisis.

One of the forerunners to adopt a probit model for predicting currency crisis, Eichengreen, Rose, and Wyplosz [21] revealed the speculative attacks on fixed exchange rate as a major concern to predict the incidence of currency crisis. In addition, employing probit model, Glick and Hutchison [22] revealed a strong and robust correlation between banking and currency crises in the emerging markets; but inclusion of developing countries restricted the casual relationship between banking and currency crisis. Whereas, Cartapanis, Dropsy, and Mametz [23] using panel and Logit regressions found that both currency overvaluation and pure contagion effects were the leading indicators of the Asian crisis. This method was also used by Falcetti and Tudela [24], Bucevska [25] among others.

In contrast to Economic Approach's summary of the probability of crisis in one number between zero and one, Signals Approach as a distinct non parametric method was pioneered by Kaminsky and Reinhart [26] who observed the macroeconomic behavior in 20 economies from 1970 to 1995 . For a preferred signaling window, the behavior of 16 selected indicators was observed in terms of their certain threshold values in order to measure the degree of financial openness, balance of payment conditions, and real and financial sector conditions. Later, Kaminsky, Lizondo, and Reinhart [27] proposed an extended the analysis based upon the persistence of the signals. Edison [28], nonetheless, extended the work of Kaminsky, Lizondo and Reinhart [27] by using wider range of countries, adding explanatory variables, testing for regional differences; but the model performed mixed as it portrayed numerous false alarms.

Signals approach, utilizing information from both crisis and non-crisis phase, explicitly considers occurrence of a crisis. It allows the policymaker to issue prompt action based on the ranking of the vulnerabilities of the indicators in accordance with their predictive power. However, imposing no restriction on explanatory variables, these models work adequately well with small samples. Some papers include applications of the EMP index to the currencies of African countries (de Macedo, Pereira and Reis, [29]), Australia (Jeisman, [30]), East Asian and Latin American countries (Tanner, [31]; Pontines and Siregar, [32]), East European countries (Hegerty, [33]), EU countries (Pentecost, Van Hooydonk, and Van Poeck, [34]; Klaasen and Jager, [35]), Finland (Spolander and Poso, [36]), and of Japan (Chen and Taketa, [37]). Frankel \& Wei [38], Frankel \& Xie, [39] developed some important discussion on this issue.

In this study we will use the signaling approach as proposed by Kaminsky, Lizondo and Reinhart [27] to identify periods while local currency situation was little erratic.

\section{Description of Some Aspects of Bangladeshi Economy}

This section discusses development of some of the important macro economic variables, such as, imports, exports, Terms of Trade, international reserves and ratio of lending to deposit interest rates of Bangladesh.

\subsection{Imports}

Bangladesh has a heavy reliance on imports. In several periods, the data of imports exceeded 90 percentile of the observed data during the sample period of 1977-2011. Mostly, the observations were above the 90 percentile when exchange rate was pegged to British Pound Sterling 
and to a basket of currencies with Pound as the intervening currency. For instance, in September, October, November and December, 1977, April, June and November, 1978, January, February, April and August, 1979, data of imports exceeded 90 percentile of the observations when exchange rate was pegged to British
Pound Sterling. In addition, the data also exceeded 90 percentile of the observed data in March, May, June and July, 1980, and October, 1981, when exchange rate was pegged to a basket of currencies with Pound as the intervening currency.

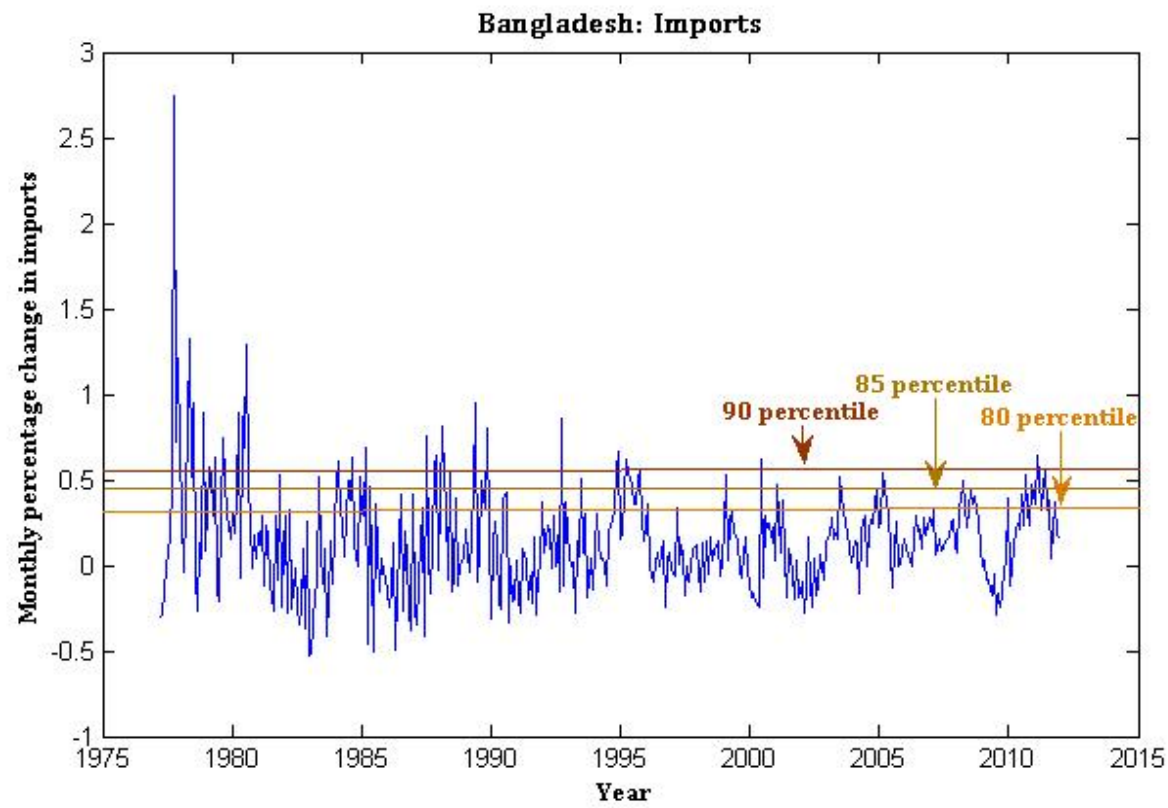

Figure 1. Imports of Bangladesh

Bangladesh moved towards another exchange rate regime in 1983. Exchange rate was pegged to a basket of currencies with US Dollar as the intervening currency, instead of Pound. This regime was followed for a relatively long span of time dating 1983-1999. Data of imports exceeded 90 percentiles of the observations several times during this regime. In April, 1983, January and August, 1984, February, 1985, June, 1986, October and November, 1987, January and May, 1988, May and October, 1989, September, 1992, October and November, 1994, March, April and September, 1995, and January, 1999, the data of imports exceeded its 90 percentile of observation.
During adjustable pegged system in 2000-2003, data of imports exceeded 90 percentile only twice: once in May, 2000, and another in June, 2003.

From 2003 and onwards, Bangladesh is following floating exchange rate system or in true essence, it is following managed floating system. In February, 2005, and August, 2010, data of imports exceeded its 90 percentile; but in 2011, it exceeded 3 times: in January, February and May.

\subsection{Exports}

Bangladesh: Exports

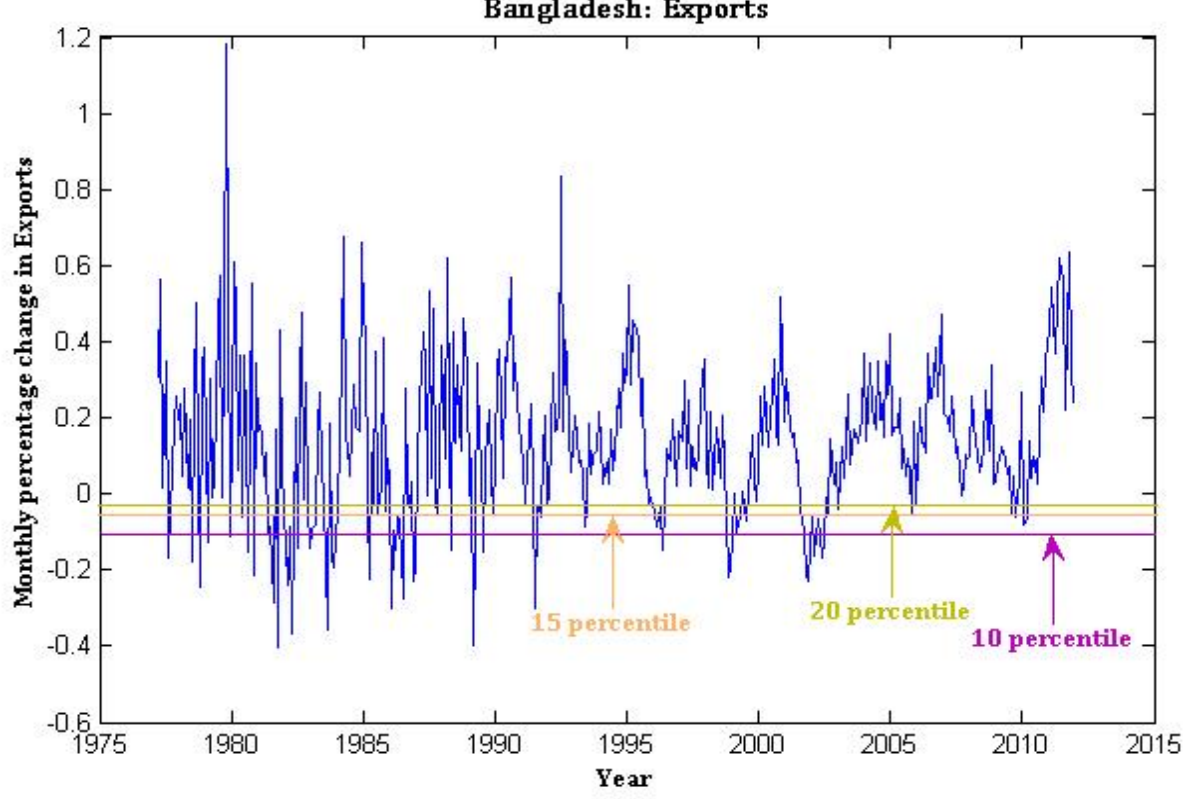

Figure 2. Exports of Bangladesh 
Export and growth of an economy are found to be interlinked. But the export base of Bangladesh is extremely narrow both in terms of composition and destination. For instance, readymade garments (RMGs) including both woven and knit, accounted for $77 \%$ of total export earnings in Bangladesh in 1999-2000. And country wise, USA, Canada and EU contributed for the market $85 \%$ of the export. This combination has made Bangladesh vulnerable to external shocks. Previously, the European ban on import of shrimp from Bangladesh had a severe impact on the industry. Generalized System of Preference (GSP) aided RMG sector of Bangladesh to flourish but contemporary EU crisis may have proven to be a threat to Bangladesh.

The data of exports was lower than 10 percentile of the observation during several periods. In July, 1977, June and October, 1978, January and November, 1979, the data of exports fell below 10 percentile of the observation when exchange rate was pegged to British Pound Sterling. Moreover, when exchange rate was pegged to a basket of currencies with Pound as the intervening currency, the data of exports was lower than its 10 percentile in August and October, 1980, May, July, September, 1981, January, February, April, June and December, 1982.

Again, when the exchange rate was pegged to a basket of currencies with US Dollar as the intervening currency, export data was lower then the 10 percentile in July, August, October and November in 1983, March, 1985, January, March, June, November and December in 1986,
April, 1988, February, March and July, 1989, June, 1991, April, 1996, October, November and December, 1998.

During the adjustable pegged system, the data of export was lower than the 10 percentile of the observed data in September, October and November, 2001, January, February, April, May and June, 2002.

In floating exchange rate regime, the data of export did not fall below its 10 percentile, but it fell below its 15 percentile in July and September, 2009, January and February, 2010.

\subsection{Terms of Trade}

Terms of trade can be explained as the share of export earnings in import payments. It steadily increased from $31 \%$ in 1981 to $67 \%$ in 2000 .

Data of terms of trade fell below its 10 percentile in quite a few times. During the pegged exchange rate system to British Pound Sterling, the data of terms of trade was lower than the 10 percentile of the observation in August, September, October, November and December, 1977, April, June and November, 1978, January, April and August 1979. In addition, during the regime when exchange rate was pegged to a basket of currency with Pound as the intervening currency, the data of terms of trade fell below its 10 percentile in March, May, July, August and October, 1980, September, 1981, January and March, 1982.

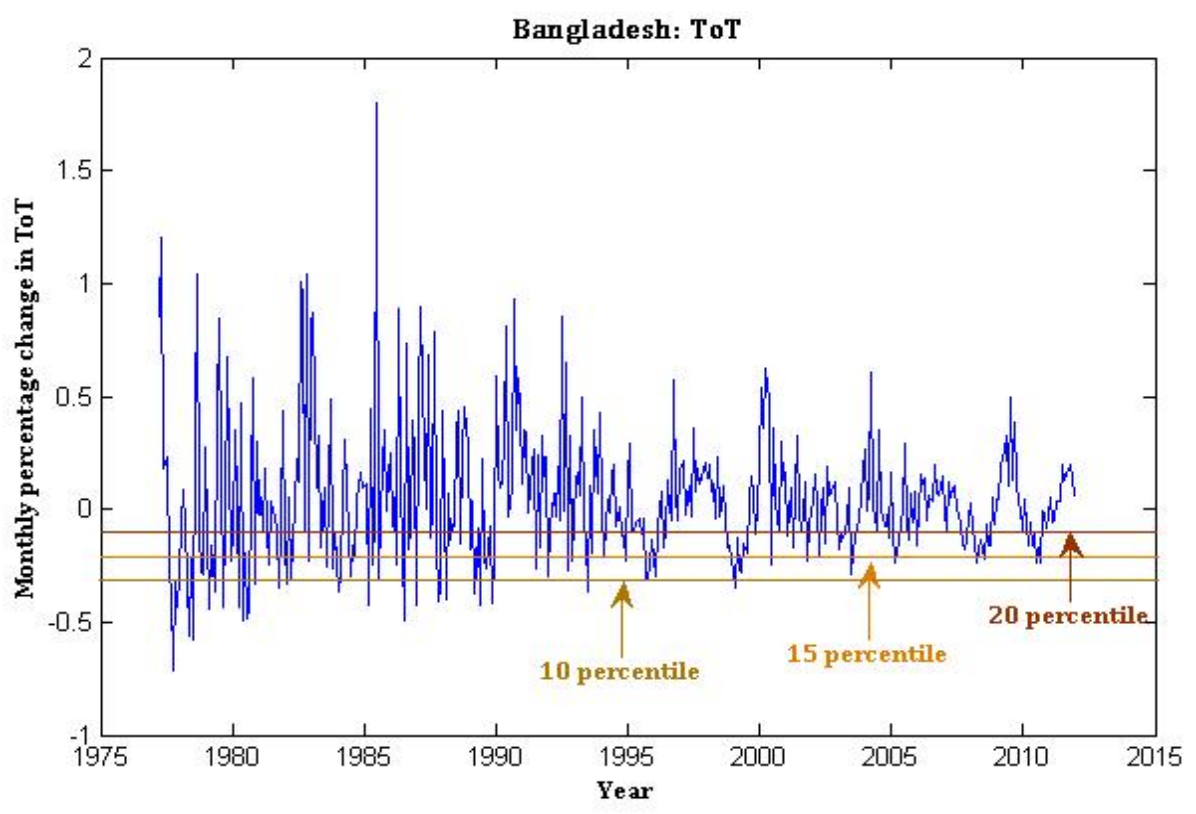

Figure 3. Terms of Trade of Bangladesh

When exchange rate pegged to a basket of currencies with US Dollar as the intervening currency, the data of terms of trade was lower than its 10 percentile in December, 1983, January and June, 1984, February and July, 1985, June and December, 1986, October and November, 1987, January, 1988, May and October, 1989, December, 1991, June, 1993, August, September, 1995, January, 1996, December, 1998, January and April, 1999.

During the floating exchange rate regime, the data of terms of trade fell below its 10 percentile in June, 2003. However, in March, 2008, June and August, 2010, the data of terms of trade was lower than 15 percentile of the observations.

\subsection{International Reserves}

Bangladesh has been following floating exchange rate system since May 31, 2003. It has been, in reality, practicing managed floating exchange rate regime as government sets exchange rate by buying and selling of foreign currencies. As a recent phenomenon, government has removed the bar to some extent to float the exchange rate accordingly. 


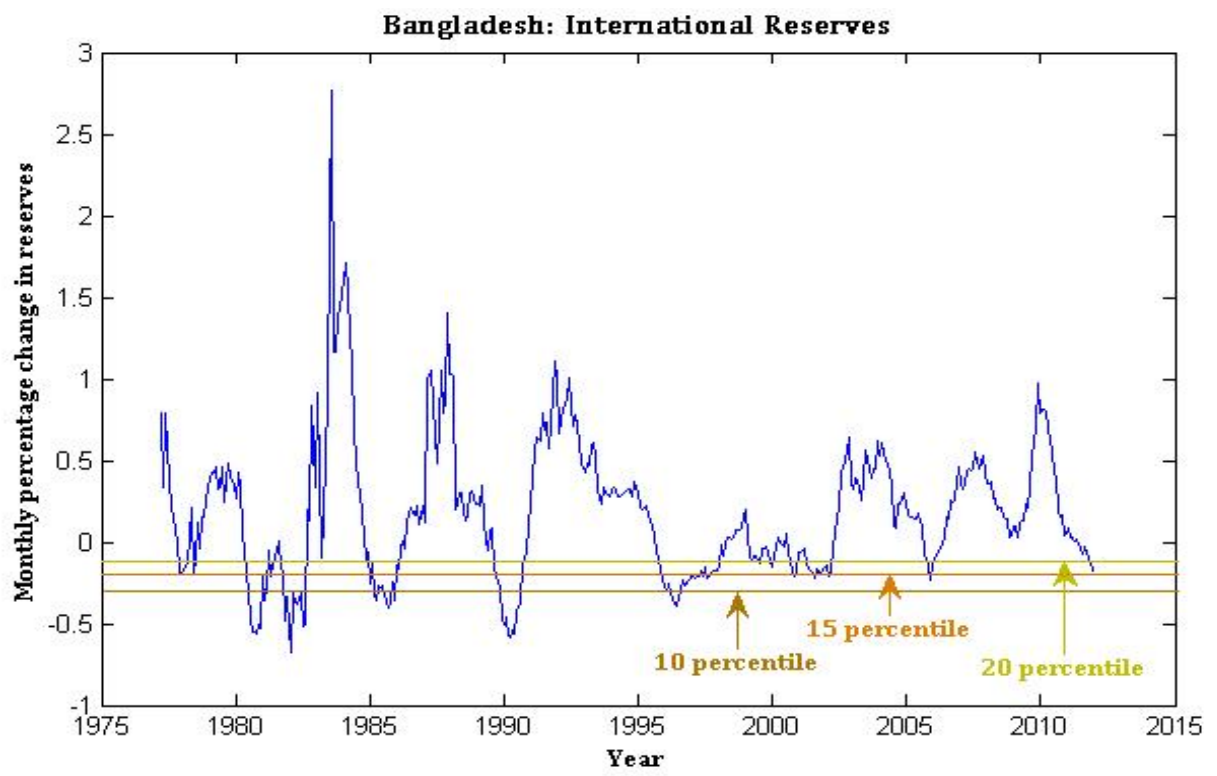

Figure 4. International Reserves of Bangladesh

When exchange rate of Bangladesh was pegged to British Pound Sterling, the data of reserves fell below its 20 percentile in November and December, 1977, January and May, 1978. Again, when Bangladesh followed pegged exchange rate to a basket of currencies with Pound as the intervening currency, the data of reserves was lower than the 10 percentile of the observations in June, July, August, September, October and November, 1980, January, February, October, November and December, 1981, January, February, March, April, May, June and July, 1982.

When Bangladesh adopted pegged exchange rate to a basket of currencies with UD Dollar as the intervening currency reserves fell below its 10 percentile in February, March, May, July, August, September and November, 1985, October, November and December, 1989, January, February, March, April, May, June and July, 1990, January, March, April, May, June and July, 1996.
In the era of floating exchange rate regime from 2003 and onwards, Bangladesh experienced the data of reserves lower than its 20 percentile in November, 2005 and November, 2011.

\subsection{The Ratio of Lending to Deposit Interest Rates}

Bangladesh maintained a constant interest rate on both lending and deposit in January, 1976-August, 1980. Over the period of October, 1980-June, 1986 both the interest on lending and deposit was set at $12 \%$ per annum. From July 1986-June, 1990, it had set the interest rate on lending at $16 \%$ per annum and the interest rate on deposit at $12 \%$ per annum. Over the rest of the period, interest rate on lending hovered around $13-16 \%$ per annum and the interest rate on deposit hovered around 5-12\% per annum.

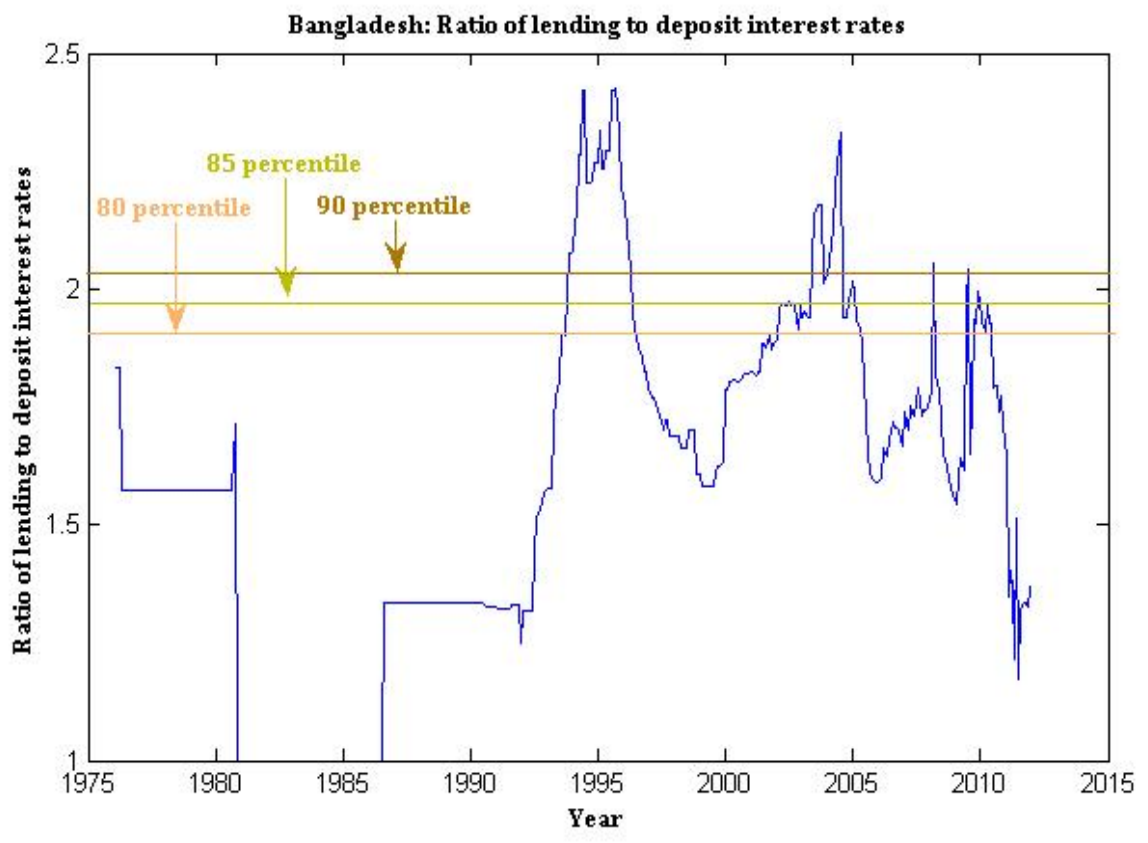

Figure 5. Ratio of lending to deposit interest rates of Bangladesh 
The data of the ratio of lending to deposit interest rates exceeded its 90 percentile though out the period of October, 1993-February, 1996 when the exchange was pegged to a basket of currencies with US Dollar as the intervening currency. In addition, in the floating exchange rate regime, the data of the ratio of the two interest rates increased over the 90 percentile in June - September, 2003, January - June, 2004, February, 2008. However, the data exceeded its 80 percentile in May, June, September, October, November and December, 2009, January-May, 2010.

\section{Methodology}

As per Kaminsky, Lizondo, and Reinhart [27] crisis is defined as a circumstance in which an attack on a currency leads to a sharp depreciation of the currency, a large decline in international reserve, or a combination of both. This definition captures both successful and unsuccessful attacks on the currency. Furthermore, it also comprehends currency attacks on different exchange rate regimes.

\subsection{Exchange Market Pressure (EMP)}

We constructed “Exchange Market Pressure (EMP)” to identify crises (ex-post) following Kaminsky, Lizondo, and Reinhart [27]. This index is the weighted average of monthly percentage changes in the exchange rate and (the negative of) monthly percentage changes in gross international reserves. Here, exchange rate is measured as units of domestic currency per U.S. dollar and international reserves are quantified in terms of U.S. dollars.

Eichengreen, Rose, and Wyplosz [40], besides exchange rate and gross international reserves, included the level of domestic interest rate in their index. They advocated for interest rate as a resort to defend the currency. But this variable was not included in Kaminsky and Reinhart [26] as the data of market-determined interest rates in developing countries do not span the entire sample period. In Bangladesh we do not experience a great deal of short and long run capital flow from rest of the world so inclusion of interest rate may not be informative.

In EMP the weights are chosen such that the two components of the index have the same conditional variance. The index is comprised of exchange rate and (negative of) gross international reserves, so the index increases with a depreciation of the currency and with a loss of international reserves. In line with that, an increase in the index portrays stronger selling pressure on the domestic currency.

\subsection{Identification of Crisis}

Crisis period can be defined when EMP index exceeds its mean by certain standard deviations; for instance, Kaminsky, Lizondo, and Reinhart [27] preferred three standard deviations, whereas Komulainen and Lukkarila [41] suggested two standard deviations. In addition, Bucevska [25] employed 1.5 standard deviations to evaluate crisis period. Therefore, there is a scope for applying subjective judgment here. However considering considerable supervision on exchange rate for developing countries like Bangladesh, deviation equal to 1.5 standard deviation can be considered sufficiently large.

\subsection{Application of EMP}

Following above discussion, in this paper, we employed EMP index based on the same conditional variance of monthly percentage change in exchange rate (national currency per USD) and monthly percentage change in international reserves.

$$
E M P=\frac{1}{\sigma_{e}} \Delta e_{t}-\frac{1}{\sigma_{r}} \Delta r_{t}
$$

Where,

$\Delta e_{t}=$ monthly percentage changes in the exchange rate

$\Delta r_{t}=$ monthly percentage changes in the gross international reserves

$\sigma_{e}=$ Standard deviation of exchange rate

and $\sigma_{r}=$ Standard deviation of reserve.

After calculating exchange market pressure index and identifying periods which can be considered as crisis we tried to relate crisis with other macroeconomic variables of Bangladeshi Economy. In that respect we identified few variables that can simultaneously give indication about possible exchange market pressure.

However the literature is far from conclusive regarding the possible list of potential variables. The common approach that is taken by the researchers is to start with a number of variables sometimes as large as one and a half dozen and then subsequently eliminate one by one until reaching to a reduced set of variables (kitchen sink approach). However we did not like that idea as most of the variables that are commonly used in such practice are strongly correlated with each other and thus are not suitable for using simultaneously in regression.

We have selected three variables that according to our evaluation have good potential to warn any possible problem in macro economy sufficiently early. These three variables are quite common in literature. However we should agree that, choosing only three of such variables is to some extent arbitrary.

We then regressed three explanatory variables with our variable "crisis", which is a binary variable and assumes a value of " 1 " whenever variable EMP leaves its mean by a certain factor times its standard deviation. Since our dependent variable is a binary variable we followed binary regression and to be specific, Logit regression. As stated above, this practice is also not alien in literature.

Then we used the concept of Granger causality in this setup. Since the whole exercise is to find out a process (set of variables) that will give us warning against any possible adverse movement in exchange rate and Granger causality tests precedence relationship between two variables it is more sensible to make use of this process.

In this paper, we have considered data of Bangladesh over the period of 1980-2011. For EMP index data is lagged by one period.

\section{Findings and Analysis}

Bangladesh after its independence practiced exchange rate pegged to British Pound Sterling from 1972 to 1979. 
Then it pegged its exchange rate to a basket of currencies with British Pound Sterling as the intervening currency. Afterwards, it was pegged to a basket of currencies with US Dollar as the intervening currency for 1980-1982. Then Bangladesh maintained exchange rate through adjustable pegged system until 2003. On a recent note, it has been maintaining a floating exchange rate system from May 31, 2003 and onwards. But Bangladesh is not following the true essence of floating exchange rate system; rather it is following Managed floating exchange rate system as Government through Central Bank engages in buying and selling of foreign currency from local market to keep the exchange rate within the ballpark that they deem appropriate considering both export and import situations after including moves of its competitors. So it is not unexpected that exchange rate will have very low volatility during the initial period considered and relatively limited afterwards. Incidentally during the period considered Bangladesh was not integrated with the rest of the world through financial highway and did not get a great deal of short term investment. The only way it was connected with the rest of the world was through real sector which did not respond much with during currency crisis. Therefore, in that respect Bangladesh was kind of immuned from the contagion effect of financial turmoil that hit many parts of the world.

This has implication in our study as this warrants lower threshold for identifying "bad" situation with respect to currency. Since during most of the time of the period considered the national currency and foreign exchange reserve situation was controlled rather than managed by the market force so any small deviation may indicate out of control external pressure. EMP calculated for Bangladesh is given in the following diagram:

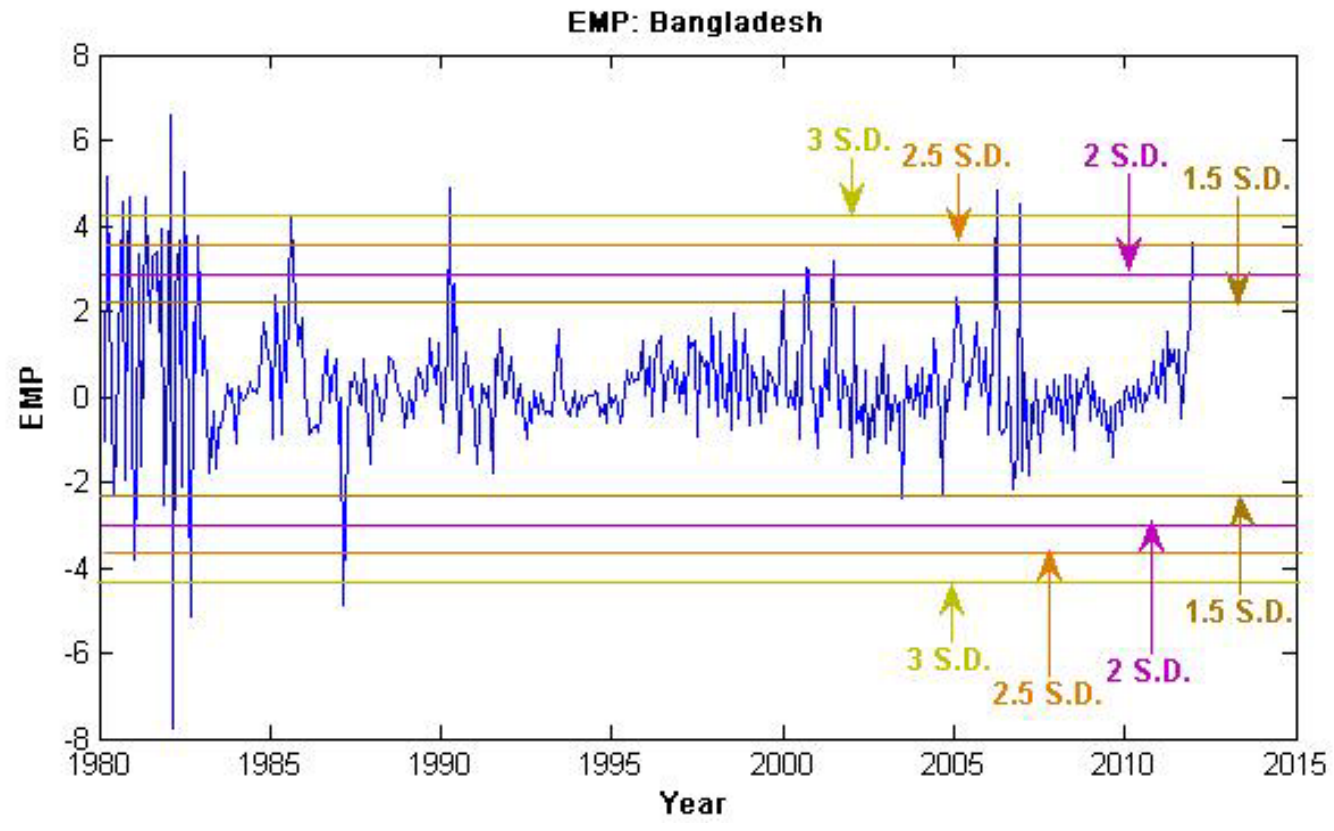

Figure 6. EMP of Bangladesh

Though Bangladesh has not yet experienced any noteworthy currency crisis, EMP portrayed March and November, 1980, April, 1981, May and June, 1982, March, 1999, and March, 2006 as the crises periods. We will consider these as potentially bad periods. Moreover, EMP fell below its lower boundary in February and August, 1982, and February, 1987. For Bangladesh we will set our threshold to 1.5 of standard deviation. It will make us more conservative but given the protective nature of operation we may consider that as a good approximation.

Then as explained in the methodology section we went for Logit regression between the variables considered and the early warning given by the EMP by crossing the threshold of 1.5 of standard deviation. We call this variable crisis. Three variables considered important are:

Ratio of M2 (broad money) and international reserve: This ratio measures whether the central bank reserves are adequate to cover the banking system liabilities in case of a bank run or a currency crisis. In crisis situation not only the foreign investors but also the local investors may feel and urge to convert their local currency holdings into foreign currency, thus holding adequate reserve is necessary for avoiding any critical situation. An economy will be more vulnerable to a confidence crisis if the ratio of money supply to the international reserves is high. First and third generation crisis theory supports such view. Expected sign of this variable is positive.

Ratio of current account to GDP: A rise (fall) in current account is generally associated with external capital inflows (outflows). An inflow of capital from outside lowers probability of occurrence of critical situation. This variable is considered important in first and second generation crisis theory. It is normally taken as a ratio of GDP to avoid any possible scale effect. Expected sign is negative for this variable.

Terms of trade: When prices of exports go up then that should strengthen a country's balance of payments position and hence lower the probability of a crisis. Expected sign is negative for this variable.

Variables are lagged by one period with an expectation that critical currency situation will be indicated by the factors by at least one month ahead. There is no consensus regarding lead period. We have tried lagging variables by three and six months but the results did not vary qualitatively. We showed our preference for shorter lag as we expect that for a closely monitored and managed economy any signal will be picked immediately. 
Since all the variables are in ratio format dimensional homogeneity is conserved and we can expect to discover true relationship between variables not a spurious one.

Due to data unavailability we have restricted our sample in regression part from January, 1999 to December 2010. It is worth mentioning that during this period Bangladeshi economy became more market oriented.

Outputs of Logistic regression are given below:

Table 1. Logit regression results

Dependent Variable: CRISIS

Method: ML - Binary Logit (Quadratic hill climbing)

Included observations: 143 after adjustments

\begin{tabular}{lllll}
\hline Variable & Coefficient & Std. Error & z-Statistic & Prob. \\
\hline C & -3.857894 & 1.932817 & -1.995995 & 0.0459 \\
M2RRESERVE(-1) & 0.004027 & 0.003826 & 1.052554 & 0.2925 \\
CURRACCRGDP(-1) & -9.210915 & 5.656863 & -1.628273 & 0.1035 \\
TOT(-1) & -0.019613 & 0.026111 & -0.751139 & 0.4526 \\
McFadden R-squared & 0.112163 & Mean dependent variable & 0.041958 \\
$\begin{array}{l}\text { S.D. dependent } \\
\text { variable }\end{array}$ & 0.201198 & S.E. of regression & 0.201085 \\
Akaike info criterion & 0.365121 & Sum squared residual & 5.620486 \\
Schwarz criterion & 0.447997 & Log likelihood & - \\
$\begin{array}{l}\text { Hannan-Quinn } \\
\text { criterion. }\end{array}$ & 0.398798 & Deviance & 22.10612 \\
\hline
\end{tabular}

Although the signs of the coefficients are expected they do not seem to be statistically significant. This can be an outcome of two possible situations. This may be due to the fact that the explanatory variables do not have significant effects on our dependent variable and that following standard econometric arguments can be considered not important enough to explain variations of dependent variable.

However, a second explanation can be pitched since the variation in our dependent variable is sparse. Only six values out of 144 observations have a value of 1.0 . So it is not unlikely that the constant coefficient will have a disproportionately large explanatory effect. We take the second explanation.

After identifying the fact the signs follow the expected pattern we turned to Granger causality tests. We tested whether the first two of our explanatory variables Granger cause the measure of EMP. Since Granger causality test is more a precedence test than causality test so such exercise is quite suitable for our purpose. The test results for ratio of M2 (broad money) and international reserve and EMP are given below:

Table 2. Granger causality results

\begin{tabular}{|c|c|c|c|}
\hline Null Hypothesis: & Observations & $\begin{array}{l}\text { F- } \\
\text { Statistic }\end{array}$ & Prob. \\
\hline $\begin{array}{l}\text { M2RRESERVE does not Granger Cause } \\
\text { EMP }\end{array}$ & 142 & 2.73128 & 0.0687 \\
\hline EMP does not Granger Cause M2RRESE & RVE & 6.84861 & 0.0015 \\
\hline
\end{tabular}

The results show that we fail to reject the null hypothesis that M2 to reserve and EMP affects each other simultaneously. This tells that whenever we see an increase in M2 to reserve we can expect that a pressure is built on exchange market.

The second Granger causality test done was between current account to GDP ratio and EMP. The results are given below:

Table 3. Granger causality results

\begin{tabular}{|c|c|c|c|}
\hline Null Hypothesis: & Observations & $\begin{array}{l}\text { F- } \\
\text { Statistic }\end{array}$ & Prob. \\
\hline $\begin{array}{l}\text { CURRACRGDP does not Granger Cause } \\
\text { EMP }\end{array}$ & 142 & 3.27601 & 0.0408 \\
\hline EMP does not Granger Cause CURRACR & RGDP & 0.41739 & 0.6596 \\
\hline
\end{tabular}

Here we have found that we fail to reject the hypothesis that ratio of current account to GDP changes before any change in EMP. However the relationship does not hold in the other way. So this ratio can act as an early warning indicator for Bangladesh.

\section{Conclusion}

In this simple minded exercise we tried to find out the possible early warning indicators of currency crisis for Bangladesh. This research can be considered redundant as Bangladesh never faced any currency crisis nor it faced anything near to that. However we do not think that the research is redundant as Bangladesh followed inward looking conservative policies regarding its openness to the rest of the world in the past. But it is very difficult to maintain such policy if it wants to get advantage of the growth spillover of the rest of the world. And in the recent years change in its outlook has been quite evident. It has implemented market oriented exchange rate policy in late 2003 and since then it is facing more and more volatility in its currency situation. It is slowly removing capital restrictions and becoming more and more integrated with the international financial flow. Also it may not be quite possible for it to conserve its position for long considering international integration for sake of development. So to our evaluation this exercise is quite timely and effective.

However, since there was no crisis in Bangladesh and the currency situation was relatively stable we did not have any data of real crisis. So in this exercise we determine when pressure got built up on exchange rate and which macro economic variable can be considered as the early warning indicator of the exchange rate crisis. We found that in some occasions exchange rate situations got little erratic but never to the extent of crisis. Using that information and running Logit regression we found that macroeconomic variables follow expected sign pattern for Bangladesh. We also found that before building up exchange rate pressure current account is most probably to show an early warning for Bangladesh. And ratio of M2 and reserve actually moves along with EMP index, so it may not be too informative for identifying currency crisis beforehand.

\section{References}

[1] Salant, S., \& Henderson, D. (1978). Market anticipations of government policies and the price of gold. Journal of Political Economy, vol. 86 (4), pp. 627-648.

[2] Krugman, P. (1979). A model of Balance-of-Payments crises. Journal of Money, Credit and Banking, vol. 11, pp. 311-325.

[3] Chiodo, A. J., \& Owyang, M. J. (2002). A case study of a currency crisis: The Russian default of 1998. Journal of Federal Reserve Bank of St. Louis, pp. 7-8.

[4] Flood, R., \& Garber, P. (1984). Collapsing exchange rate regimes: Some linear example. Journal of International Economics, vol. 17.

[5] Jeanne, O. (2000). Currency crises: A perspective on recent theoretical developments, Special papers in International Economics No. 20, International Finance Section, Princeton University.

[6] Obstfeld, M. (1994).The logic of currency crises. NBER Working Paper No. 4640. Cambridge, Massachusetts: National Bureau of Economic Research.

[7] Obstfeld, M. (1996). Models of currency crises with self-fulfilling features. European Economic Review, vol. 40, pp. 1037-1047. 
[8] Obstfeld, M., \& Rogoff, K. (1995). The mirage of fixed exchange rates. Journal of Economic Perspectives, vol. 9, pp. 73-16.

[9] Bensaid, B., \& Jeanne, O. (1997). The instability of fixed exchange rate systems when raising the nominal interest rate is costly. European Economic Review, vol. 41, pp. 1461-1478.

[10] Velasco, A. (1996). Fixed exchange rates: Credibility, flexibility and multiplicity. European Economic Review, vol. 40, pp. 10231035.

[11] Jeanne, O. (1997). Are currency crises caused by the fundamentals or by self-fulfilling speculation? A test. Journal of International Economics, vol. 43, pp. 263-286.

[12] Radelet, S. \& Sachs, J. (1998). The East Asian financial crisis: Diagnosis, remedies, prospects. Harvard Institute for Development.

[13] Masson, P. (1998). Contagion: Monsoonal effects, spillovers, and jumps between multiple equilibria. IMF Working Paper No. 98/142.

[14] Chang, R., \& Velasco, A. (2001). A model of financial crises in emerging markets. The Quarterly Journal of Economics, vol. 116 (2), pp. 489-517.

[15] Burnside, C., Eichenbaum, M., \& Rebelo, S. (2001). Hedging and financial fragility in fixed exchange rate regimes. European Economic Review, vol. 45, pp. 1151-93.

[16] Burnside, C., Eichenbaum, M., \& Rebelo, S. (2004). Government guaranties and self-fulfilling speculative attacks. Journal of Economic Theory, vol. 119 (1), pp. 31-63.

[17] McKinnon, R., \& Pill, H. (1996). Credible liberalizations and international capital flows: The over borrowing syndrome. In T. Ito, \& A. Krueger (Eds.), Financial Deregulation and Integration in East Asia. Chicago: University of Chicago Press.

[18] Chang, R., \& Velasco, A. (1998). Financial crises in emerging markets: A canonical model. New York University Economic Research Reports, pp. 98-21.

[19] Krznar, I. (2004). Currency crisis: Theory and practice with application to Croatia. Working Paper W-12. Croatian National Bank.

[20] Sachs, J., D., Tornell, A., \& Velasco, A. (1996). Financial crises in emerging markets: The lessons from 1995. Brookings Papers on Economic Activity: 1, Brookings Institution, pp. 147-215.

[21] Eichengreen, B., Rose, A. K., \& Wyplosz, C. (1996). Contagious currency crises. CEPR Discussion Paper No. 1453 presented at the Centre for Economic Policy Research, London.

[22] Glick, R., \& Hutchison, M. (2000). Banking and currency crises: How common are the twins?. Working Paper, No.01/2000, the Hong Kong Institute for Monetary Research.

[23] Cartapanis, A., Dropsy, V., \& Mametz, S. (2002). The Asian currency crises: Vulnerability, contagion, or unsustainability. Review of International Economics, vol. 10 (1), pp. 79-91.

[24] Falcetti, E., \& Tudela, M., (2006). Modeling currency crises in emerging markets: A dynamic probit model with unobserved heterogeneity and auto correlated errors. Oxford Bulletin of Economics and Statistics, vol. 68 (4), pp. 445-471.

[25] Bucevska, V. (2011). An analysis of financial crisis by an early warning system model: The case of the EU candidate countries. BEH - Business and Economic Horizons, vol. 4 (1).
[26] Kaminsky, G., \& Reinhart, C. M. (1996). The twin crises: The causes of banking and balance of payments problems. International Finance Discussion Paper No. 544 presented to the Board of Governors of the Federal Reserve System, Washington.

[27] Kaminsky, G., Lizondo, S. \& Reinhart, C. M. (1998). Leading indicators of currency crisis. Staff Papers, International Monetary Fund, vol. 45 (1).

[28] Edison, H. (2000). Do indicators of financial crises work? An evaluation of an Early Warning System. Journal of Finance and Economics, vol. 8, pp. 11-53.

[29] de Macedo, J.B., Pereira L.B., and A.M. Reis (2009). "Comparing Exchange Market Pressure across Five African Countries,” Open Economic Review, Vol. 20, pp. 645-682.

[30] Jeisman, S. (2004). "Exchange Market Pressure in Australia," Discussion Paper No 183, Queensland University of Technology.

[31] Tanner, E., (2001). "Exchange Market Pressure and Monetary Policy: Asia and Latin America in the 1990s,” IMF Staff Papers, International Monetary Fund, Vol. 47: 3.

[32] Pontines, V., and R.Y. Siregar (2006). "Fundamental Pitfalls of Exchange Market Pressure - Based Approaches to Identification of Currency Crises,” Discussion Paper No. 0602, University of Adelaide.

[33] Hegerty, S.W. (2009). "Capital Inflows, Exchange Market Pressure, and Credit Growth in Four Transition Economies with Fixed Exchange Rates,” Economic Systems, Vol. 33, pp. 155-167.

[34] Pentecost, E.J., Van Hooydonk C., and A. Van Poeck (2001). "Measuring and Estimating Exchange Market Pressure in the EU," Journal of International Money and Finance, Vol. 20, pp. 401-418.

[35] Klassen, F., and H. Jager (2008). "Definition-consistent Measurement of Exchange Market Pressure," Unpublished manuscript (earlier version has appeared as Tinbergen Institute Discussion Paper 06-112/2).

[36] Spolander, M., and M. Poso, (1997). "Estimating Exchange Market Pressure and the Degree of Exchange Market Intervention for Finland during the Floating Exchange Rate Regime," BoF Disccussion Papers 4/97, Bank of Finland.

[37] Chen, S.-S., and K. Taketa (2006). "An Assessment of Weymark's Measures of Exchange Market Intervention: The Case of Japan," IMES Discussion Paper Series 2006-E-3, Bank of Japan.

[38] Frankel, J. \& S.-J. Wei (2008). Estimation of De Facto Exchange Rate Regimes: Synthesis of the Techniques for Inferring Flexibility and Basket Weights." IMF Staff Papers 55 (3): pp. 384416.

[39] Frankel, J. \& D. Xie (2010). Estimation of De Facto Flexibility Parameter and Basket Weights in Evolving Exchange Rate Regimes." American Economic Review 100 (2): pp. 568-72.

[40] Eichengreen, B., Rose, A. K., \& Wyplosz, C. (1995). Exchange market mayhem: The antecedents and aftermath of speculative attacks. Economic Policy, vol. 21, pp. 249-312.

[41] Komulainen, T., \& Lukkarila, J. (2003). What drives financial crises in emerging markets. Emerging Markets Review, vol. 4. 